\title{
MANAGING DROUGHT: SHORT TERM STRATEGIES IN SEMI ARID REGIONS -A CASE STUDY
}

\author{
Vijaykumar M.Devappa ${ }^{1}$ \\ Prof. \& Head Civil Engg, Dept. \& M.Tech, Courses BKIT Bhalki-585328, Dt Bidar, Karnataka \\ vmdevapa@gmail.com
}

\begin{abstract}
Drought management needs multidisciplinary action. Interdisciplinary efforts among the experts in various fields of the droughts prone areas are helpful to achieve tangible and permanent solution for this recurring problem. The Gulbarga district having the total area around 16, 240 sq.km, and accounts 8.45 per cent of the Karnataka state area. The district has been situated with latitude $17^{\circ} 19^{\prime}$ $60^{\prime \prime}$ North and longitude of $76^{\circ} 49^{\prime} 60^{\prime \prime}$ east. The district is situated entirely on the Deccan plateau positioned at a height of 300 to $750 \mathrm{~m}$ above MSL. Sub-tropical, semi-arid type is one among the drought prone districts of Karnataka State. The drought management is very important for a district like Gulbarga. In this paper various short term strategies are discussed to mitigate the drought condition in the district.
\end{abstract}

Keywords: Drought, South-West monsoon, Semi-Arid, Rainfall, Strategies etc.

\section{INTRODUCTION}

By the experience of the past century the Indian arid and semiarid zones experience drought situations once in alternate three years [1]. Prolonged droughts are experienced about five times in a century, leading to severe scarcity of food fodder, fuel, fruits, flowers and fiber. [2] Have defined 'drought week' as a week receiving rainfall equal to or less than half of the average rainfall of the week [3] analyzed the drought conditions during the south-west monsoon season using the definitions on the basis of rainfall deficits from normal as; between 11 to 25 percent- slight drought; between 26 to50 percent- moderate drought; and if it is greater than 50 percent-severe drought. [4] analyzed monthly and yearly drought for agricultural planning. Above definitions were used to study the drought situation at different corner of the country [5];[6];[7];[8](e.g. Dabral; 1996; Kumar and Kumar, 1989; Ray et al. 1987; Ranade and Gupta, 1992). Erratic and scanty rainfall, excessive depth to ground water, absence of perennial rivers, and porous nature of soils are interrelated. The major causes contributing to drought are increased pressure of both human and livestock population during the previous century which had imposed tremendous pressure on natural resources particularly in the arid and semiarid regions.

Drought is an insidious hazard of nature. It should not be viewed as merely a physical phenomenon or natural event its impact on society result from the interplay between a natural event and the demon of the people, place on water supply [9].The drought management is very important for a district like Gulbarga. During these years a large numbers of relief works were required to start by various Government and Non- government agencies in the district in order to mitigate the drought impact.

In most of the developing world, drought vulnerability constitutes a threat to livelihoods, the ability of maintain productive systems and healthy economics. Droughts cause maximum damage in dry and semiarid tropical regions of India. With ever increasing population, there is a severe stress of water resource in general and during periods of droughts in particular [10]. Certain measures can be taken to reduce the adverse impacts of drought. They can be short term and long term. Drought prone areas can be made less vulnerable to drought associated problems through soil moisture conservation measures, water harvesting practices and integrated water management strategies would be needed for managing available water resources optimally. Droughts and water shortage can be managed through focused research and analysis for effective

\subsection{Data Collected}

For the detailed study of the Gulbarga district, the various data were collected from district Statistical department, Zilla Panchayth Gulbarga, office of the Deputy Commissioner Gulbarga[11].

\subsection{Study Area}

Gulbarga district is one among the drought prone districts of Karnataka State. All the ten talukas of the Gulbarga district were identified as drought prone talukas. Drought management needs multidisciplinary action. Interdisciplinary efforts among the experts in various fields of the droughts prone areas are 
helpful to achieve tangible and permanent solution for this recurring problem. There is a need of the hour, how to deal with droughts and manage available resources optimally. With increasing population and predictions of global climate change and increasing water scarcity, management of drought will have an important role to play in ensuring food security and better livelihood for millions of people. The lessons learnt from droughts in the past can be utilized in building up the necessary infrastructure and evolving management systems for sustainable use of natural resources.

The drought management is very important for a district like Gulbarga. During these years, large numbers of relief works were started by various Government and Non- government agencies in the district in order to mitigate the drought impact. Generally the public efforts mounted to deal with the drought situations and they are in the form of relief measures aimed at providing food security, employment opportunities and some sort of development work. As such, in effect these are basically efforts in mitigating the consequences of drought, rather than containing the drought itself. It is necessary to make a distinction between these two phases in managing the drought. Problems of tackling drought impacts are complex and multifaceted. Therefore Strategies to deal with these problems require multi- institutional and multi-disciplinary resource building approach with farmer at center stage. Various data product from field GPS maps, remote sensing etc can be used effectively in GIS and easily converted into a common scale and resolution required for integration. Because of the spatial nature, data of natural hazards like droughts can be analyzed and effective planning can be made using GIS.

\subsection{Location, Extent and Accessibility}

Gulbarga district is one of the 30 districts of Karnataka state in southern India. Gulbarga city is the administrative headquarters of the district. In Persian language Gul means flower and berg means leaf thus making Gulbarga once a land of lavish living. This district is situated in northern Karnataka between $76^{\circ} .04^{\prime}$ and $77^{\circ} .42$ east longitude, and $17^{\circ} .12^{\prime}$ and $17^{\circ} .46^{\prime}$ north latitude, covering an area of $10,951 \mathrm{~km}^{2}$. This district is bounded on the west by Bijapur district and Sholapur district of Maharashtra state, on the north by Bidar district and Osmanabad district of Maharashtra state, on the south by Yadgir district, and on the east by Ranga Reddy district of Andhra Pradesh state.

The city of Gulbarga was founded by the Bahmani Sultans in the 14th century as their capital. However the history of the region dates back to the 6th Century when the Rashtrakutas gained control over the area, but the Chalukyas regained their domain and reigned for over two hundred years. Around the close of the 12th century the Yadavas of Devagiri and the Hoysalas of Halebidu took control of the district. The present Gulbarga District and Raichur District formed part of their domain. The northern Deccan, including the district of
Gulbarga, passed under control of the Muslim Delhi. The revolt of the Muslim officers appointed from Delhi resulted in founding of the Bahmani Sultanate in 1347 by Hassan Gangu, who chose Gulbarga (Ahsenabad during this period) to be his capital. From 1724 to 1948 the territory occupied by the present-day Gulbarga district was part of Hyderabad state ruled by the famous Nizams. It was integrated into India in September 1948.

\subsection{Geography}

Gulbarga is situated in Deccan Plateau located at $17.33^{\circ} \mathrm{N}$ $76.83^{\circ} \mathrm{E}$ and the general elevation ranges from 300 to 750 meters above mean sea level. Two main rivers, Krishna and Bhima, flow in the district. Black soil is predominant soil type in the district. The district has a large number of tanks which, in addition to the rivers, irrigate the land. The Upper Krishna Project is major irrigation venture in the district. Bajra, toor, sugarcane, groundnut, sunflower, sesame, castor bean, black gram, jowar, wheat, cotton, ragi, Bengal gram, and linseed are grown in this district.

The weather in Gulbarga consists of 3 main seasons. The summer which spans from late February to mid-June It is followed by the south west monsoon which spans from the late June to late September heavy rainfall may go up to $750 \mathrm{~mm}$. It is then followed by dry winter weather until mid-January. Barring the hot summer months, the salubrious weather of Gulbarga makes a visit to this historical city a pleasant one. Gulbarga district presently comprises the following 7 talukas Gulbarga (Fig.2) Aland Afzalpur Jevargi Sedam Chitapur Chincholi. Temperatures during the different seasons are: Summer: 38 to $44{ }^{\circ} \mathrm{C}$ Monsoon: 27 to $37{ }^{\circ} \mathrm{C}$ Winter: 11 to 26 ${ }^{\circ} \mathrm{C}$

\subsection{Demographics}

According to the 2011 census Gulbarga district has a population of 2,564,892, roughly equal to the nation of Kuwait or the US state of Nevada. This gives it a ranking of 162nd in India (out of a total of 640). The district has a population density of 233 inhabitants per square kilometre (600/sq mi). Its population growth rate over the decade 2001-2011 was $17.94 \%$.Gulbarga has a sex ratio of 962 females for every 1000 males, and a literacy rate of $65.65 \%$.Kannada is the predominant language spoken in this district. Dakhni Urdu are also spoken in this district. Hinduism and Islam are principle religions followed in this district. The Urdu speaking Muslim population is heavily influenced by Hyderabad.

\subsection{Transport}

Gulbarga city is well connected by road and rail from Bangalore, Hyderabad, Mumbai \& other major cities. Local Transport: Taxis and auto rickshaws are available for getting around the city at fairly reasonable rates. NEKRTC city buses also ply within the city and also go to the nearby towns and 
villages. KSRTC runs the bus service to other cities and villages. Also there are plenty of private bus services. The Bidar-Srirangapatna state highway made travel easy to Bangalore, and neighboring states of Maharashtra, Goa. There are many private services running Volvo buses between Bangalore-Gulbarga, Mumbai-Gulbarga. Gulbarga is well served by major rail lines and is connected to all major parts of India such as Mumbai, Delhi, Bangalore, Chennai, Ahmadabad, Rajkot, Agra, Bhopal, Coimbatore, Kanyakumari, Trivandrum, Bhubneshwar etc. Nearest Airport is Hyderabad International Airport $220 \mathrm{~km}$ from City. A new airport in Gulbarga is under construction.

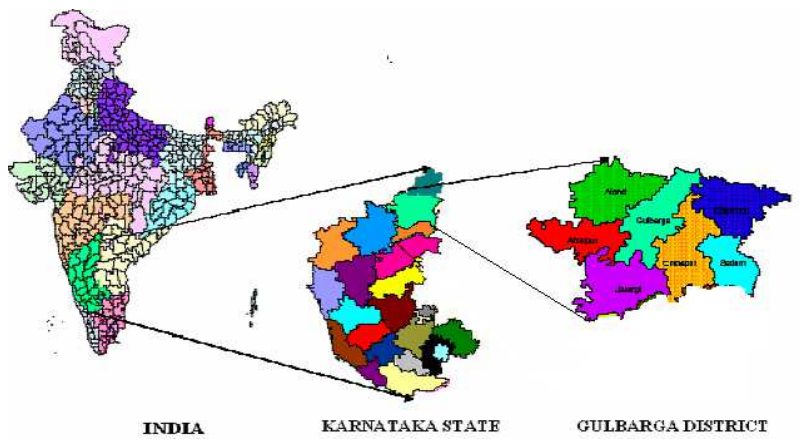

Fig.1 Location map of Gulbarga district, Karnataka, India

\subsection{Agriculture and Crops}

The total cultivated area in Gulbarga district is 12.55 lakh hectares, out of which kharif area is 6.66 lakh hectares and Rabi area is 5.89 lakh hectares. The district normally has three cropping seasons namely (A Report of Government of Karnataka, Contingency plan for Drought Relief Work, 2003) kharif, Rabi, and summer. The source of irrigation is mostly canal system under Upper Krishna Project and rest through medium irrigation project and to some extent by bore well and tank irrigation. The (major) principal crops grown in the district are tur, bajra, ground nut, sunflower and Rabi jawar. Sugarcane is also grown to an extent of 7000 hectares. Red gram is the single monocrop, occupying the highest area in the state and in the country. The district has a total of 2, 41,482 small and marginal farmers. The district is economically backward with 80 per cent of the population depending upon the agriculture. Most of the families reside in villages. The Gulbarga district has a long history of continuous droughts. The district also has very poor human development index. The total number of agricultural labours is $4,44,440$. The only major irrigation project in the district is Upper Krishna Project, which covers 3 talukas, namely, Shahapur, Shorapur and Jewargi, providing irrigation to 1.96 lakh hectares of land. The other medium irrigation projects are Chandrampalli in Chincholi taluka covering 4010 hectares, Hattikuni, and Soudagar projects in Yadgir taluka covering 3,500 hectares. At present, out of total cultivated area only 18 per cent is under irrigation. The remaining cultivated area totally depends on rainfall only. With the completion of ongoing irrigation projects like Bennethora, Gandorinala and Amarja, the area under irrigation will be increased to 35 per cent cultivable area.

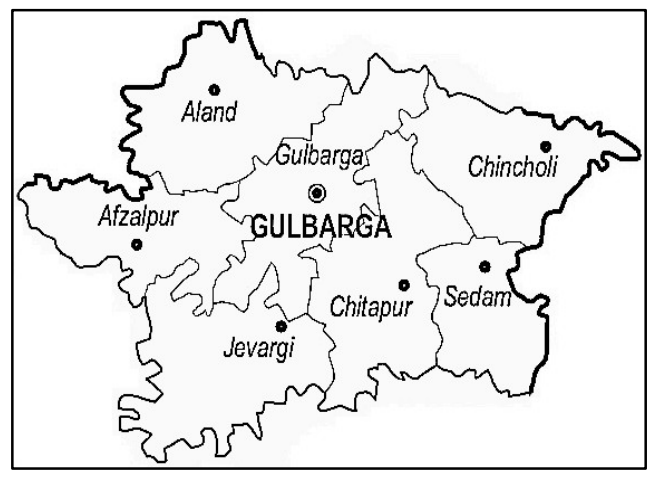

Fig.2 map of Gulbarga district, Karnataka, India

\section{STRATEGIES FOR EFFICIENT MANAGEMENT OF DROUGHTS}

Development of appropriate and viable drought management strategies, to meet the challenge posed by the occurrence of droughts year after year, should be the ultimate goal of drought research.

\subsection{Short Term Strategies}

Following short term measures are being required to combat drought in the district.

\subsection{Execution of Labour Oriented Schemes}

The primary effect of drought is failure of crops, reduction in agricultural production and increased unemployment among laborers with direct economic consequences, leading to ill health and under nutrition in the community. The most vulnerable segments of the population to drought are weaker sections of the society, such as those belonging to SC/ST communities, rural landless labourers, marginal farmers and small farmers. Frequent drought affected region for the district like Gulbarga, implementation of relief and development works with proper planning will be required after adequate investigation for creating suitable and productive assets. The maximum population density of 20 per cent is observed in Gulbarga taluka and minimum population density of 7 per cent is observed in Afzalpur and Jewargi talukas of the district. About 10.10 lakh main workers, about 3.4 lakh marginal workers and about 17.8 lakh of non-workers are observed in the district. It had been found that the distribution of workers in the district is not uniform in all talukas of the district and also a well-defined labour oriented programme could bring considerable relief to the landless labourers and reduce the migration considerably. The various Government and Non- 
government organizations of the district should involve in such schemes. Remote sensing and geographical information system could be used efficiently for identification of places for the construction of various projects to give work to various labour categories.

Table-1 Classification of workers in various talukas of Gulbarga district Gulbarga

\begin{tabular}{|l|r|r|l|l|l|l|l|l|l|l|}
\hline Taluka & \multicolumn{6}{|c|}{ Classification of Workers } & & & \\
\hline & Workers & \multicolumn{3}{|c|}{ Non-Wo } & Cultivators & & \multicolumn{3}{|c|}{ Agricultural Labourers } \\
\hline & Main & Marginal & Total & Male & Female Total & Male & FemaleTotal \\
\hline Afzalpur & 54890 & 21966 & 103215 & 18588 & 4028 & 22616 & 15501 & 21604 & 37105 \\
\hline Aland & 106212 & 46407 & 144517 & 34093 & 13666 & 47759 & 29070 & 47847 & 76917 \\
\hline Chincholi & 80993 & 31026 & 111627 & 23919 & 9533 & 33452 & 18431 & 34803 & 53234 \\
\hline Chithapur & 113667 & 27554 & 225581 & 22816 & 7361 & 30177 & 19320 & 27586 & 46906 \\
\hline Gulbarga & 182007 & 40685 & 452991 & 25789 & 8274 & 34063 & 20695 & 30201 & 50896 \\
\hline Jewargi & 78852 & 30043 & 126359 & 24906 & 5750 & 30656 & 20443 & 36678 & 57121 \\
\hline
\end{tabular}

\subsection{Planning of Famine Relief Measures}

Normally, the Executive Engineer, ZPE Division, Executive Engineer KUWS and D.B. Gulbarga are taking the stock of ground realities prevailing in the district, and they should prepare an action plan for providing drinking water to the problem facing villages and urban areas respectively and submit the report to task force committees. The action plan has to be submitted to the Deputy Commissioner by taluka thahasildars to consolidate them and to submit to Revenue Department and Government for release of funds under Calamity Relief Fund, wherever Zilla Panchayat and Local bodies are not in a position to make the good requirements out of their own sources of funds. The various guidelines should be followed as per RS and GIS for planning famine relief measures.

\subsection{Transportation of Drinking Water from Outside}

\section{Regions}

Priority will be given to supply of drinking water by tankers to the severe drought affected areas. Transportation of drinking water from the water available place works costlier but save the life of the people and livestock during drought periods.

\subsection{Public Distribution System}

To mitigate the impact of drought as per the direction given by State and Central Government, the Gulbarga district has to develop a reliable public distribution system for distribution of food grains. In this context for efficient management, proper watching of the working of the system is required.

\subsection{Diversification of Economic Activities}

Diversification of economic activities is an important aspect of improving the drought situation. Drought usually affects farming activities; however, other non-farm based economic activities continue to provide employment and income to the people of the region. These farming activities which need to be supplemented and encouraged during drought period

(a) Among diversified activities crop husbandry, poultry and other skill based activities should be taken up which are not dependent on agriculture itself.

(b) Agro- processing is an important lacuna in the drought prone areas. This will not only provide employment but also enhances value addition to the products. This can be taken up for millets like Jowar, Sajje, save as well as for the crop residues.

The industrial activities of agro processing should be taken up by the District Industrial Department, Private Industries, and Non-Government Organizations and Private Capital Ventures. Diversification of economic activities in a proper way helps the people of the district to tolerate the drought followed by famine in the district.

\subsection{Employment Generation Programme}

There are around 2.8 lakh male cultivators are present in the district. Among agricultural labours, 1.92 lakh male and 3.5 lakh female are present in the district. More migration of the people in the district is observed during the drought period. Hence, availability of employment at the time of stress due to drought in the region is one of the major problems. Employment is usually available on the drought relief works; however, it is sporadic and does create an assurance among the farming community. Therefore, provision off- farm employment happens to be one of the important problems in these regions. Employment Assurance Schemes certainly help to provide employment during the lean period. Similarly, the drought relief works provide employment only at the time of drought. However, it is suggested that some of the production oriented employment programme with an underlying skill enhancement should be taken up in the districts so that the employment is available around the year. This will supplement farming activities, and instill confidence among the farmers. Such programme should be taken up by Non-Governmental Organizations where the production activity itself should sustain the programme in the long run. Efforts will be made to provide employment to agricultural labours in the district particularly in rural areas at village level under various labour oriented schemes taken up by Zilla Panchayat and other bodies, such as Employment Assurance Scheme (EAS), Water Shed Development Programme, Shehri Rozger Yojana (Urban Employment Scheme) and also Hundred Days Guarantee Schemes in rural areas (State and Central schemes). 


\subsection{Food for Work Programme}

The migration of the people in the district is slightly higher during drought period. The several works to be taken up under Employment Generation scheme (E.G.S) will depend on local area requirement and labour oriented works such as road works, digging and deepening of wells, desilting of tanks and ponds etc. While selecting such types of works in the drought district, every effort should be made to prevent migration of people. Under Sampurna Gramina Rozghar Yojana (Complete Rural Employment Scheme) in Gulbarga district the total men generated is 35.0 lakh and the total food grains utilized under this scheme is 12,429 tones.

\subsection{Increasing Irrigation Potential}

The net irrigated area in the district is 2.10 lakh hectares. In this, 77.23 per cent is from canals, 1.91 per cent is from reservoirs and 14.92 per cent is from wells The total number of lift irrigation schemes in the district are 1049 and maximum lift irrigation is present in the Shorapur (385 numbers) and minimum lift irrigation is present in Chincholi, Chithapur, Gulbarga and Jewargi talukas. The total water available from other water sources in the district is 5529 numbers and maximum water sources present in Yadgir taluka (11609 hectare) and minimum water source in Chithapur taluka of the district.

The foremost and the best ways of preventing the drought are to provide assured irrigation to all the cultivable land. At present, out of nearly 13,993, 81 hectares cultivated in Gulbarga district, nearly $11,79,856$ hectares is under rain fed conditions. It is estimated that even after achieving the full irrigation potential, the major cultivable area will remain still dependent on rain..A proper planning is required using the advanced technology like remote sensing and geographical information system in the district to plan and locate the various water storage structure to increase irrigation potentials.

\subsection{Management of Population in Drought Affected}

\section{Area}

Migration of population to neighboring States/districts reflects the decrease in employment opportunities in the villages of the district and highlights the need for strengthening incomegenerating activities for the rural poor. In the district, there are around 5.2 lakhs of male and 2.73 lakhs of female literates in the rural areas, 2.93 lakhs of male and 2.11 lack female literates in urban areas. The literates in various talukas in rural and urban with total numbers of male and female are shown in and. From the table, it is observed that the female literacy rate is substantially low in Gulbarga district. This may be due to an unchecked population growth and low educational and low infrastructural facility in the district. To increase the literacy rate in the district two measures could be taken viz. a) Literacy should be made more popular in the district through street plays like Saksharatha Andolana (literacy programme) etc. b) To Increase the educational infrastructure, at least one primary school per village for every 500 households are to be provided. In this regard, Department of Social Welfare, Health, Education, NGOs and Zilla Panchayats should work together and proper measurers should be taken.

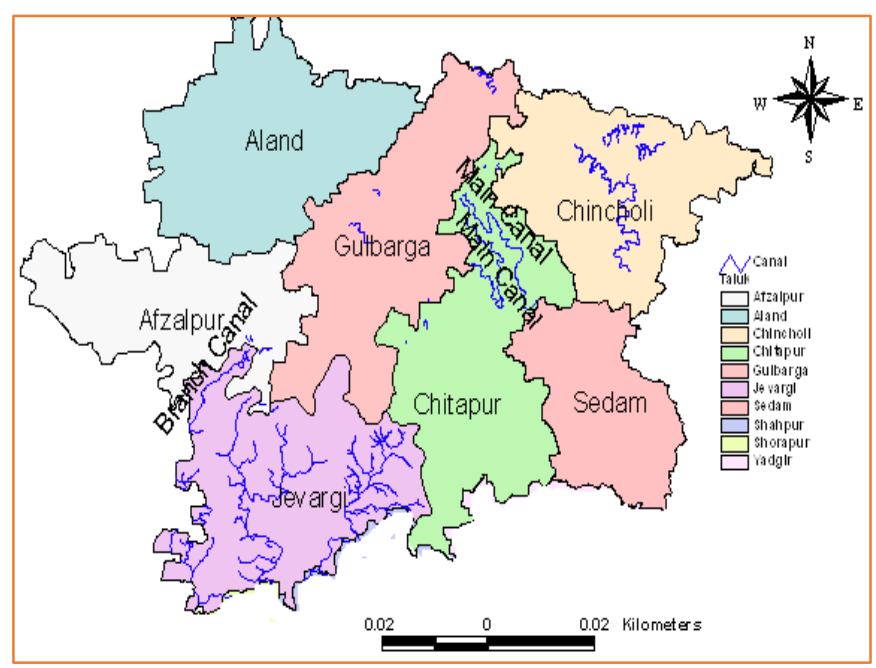

Fig3. Map showing the irrigation by canal in Gulbarga district

Table2. Literates in various talukas of Gulbarga district [12]

\begin{tabular}{|l|l|l|l|l|l|l|l|l|l|}
\hline \multirow{3}{*}{ Taluka } & \multicolumn{7}{|l|}{ Literates } \\
\cline { 2 - 10 } & Rural & \multicolumn{7}{l|}{ Urban } & \multicolumn{1}{l|}{ Total } \\
\cline { 2 - 10 } & Male & Female & Total & Male & Female & Total & Male & Female & Total \\
\hline Afzalpur & 43053 & 23402 & 66455 & 6025 & 3998 & 10023 & 49078 & 27400 & 76478 \\
\hline Aland & 72976 & 40574 & 113550 & 10916 & 7182 & 18098 & 83892 & 47756 & 131648 \\
\hline Chincholi & 52561 & 28252 & 80813 & 5661 & 3600 & 9261 & 58222 & 31852 & 90074 \\
\hline Chithapur & 52616 & 28677 & 81293 & 41769 & 28165 & 69934 & 94385 & 56842 & 151227 \\
\hline Gulbarga & 64761 & 35559 & 100320 & 159519 & 119649 & 279168 & 224280 & 155208 & 379488 \\
\hline Jewargi & 50465 & 24476 & 74941 & 5983 & 3947 & 9930 & 56448 & 28423 & 84871 \\
\hline Sedam & 32583 & 18328 & 50911 & 13022 & 9138 & 22160 & 45605 & 27466 & 73071 \\
\hline Total & 369015 & 199268 & 568283 & 242895 & 175679 & 418574 & 611910 & 374947 & 986857 \\
\hline Source & Sta & & & & & & & & \\
\hline
\end{tabular}

Source: Statistics of the Gulbarga district, published by Z.P. Gulbarga

\subsection{Management of Livestock in Drought Affected}

\section{Area}

In semi-arid areas, which are frequently subjected to drought, planning of livestock management is important as that of pastures in order to keep production at a suitable level, 
compatible with its economic development where communications and cost of transport neither allow the import of fodder to the drought stricken area nor the movement of livestock to areas not affected by drought. If there is no other defensive planning against the ravages of drought, the farmer is faced with the choice of selling his stock at low prices and buying back after the drought at high prices, or allowing them to die of hunger. This is true as for as Gulbarga district is concerned. The scientific experiments and education should provide the knowledge on which adequate individual action may be taken to reduce the ravages of drought.

According to recent census, the total number of cattle in the district is $22,25,864$. In the district, the maximum cattle percentage is in Yadgir taluka (18.3 per cent) and minimum cattle percentage is in Afzalpur taluka (5.08 per cent). The number of buffalos present in the district is 2, 27,249. The maximum buffalos are present in Shorapur taluka 89,303 and minimum in Afzalpur (12224). The total indigenous cattle present in the district is $8,19,956$, with maximum in Yadgir (119401) and minimum in Sedam taluka (61925 numbers)[13].The total number of cross breed present in the district is 13,383 with maximum in Gulbarga (5105) and minimum in Jewargi taluka (66 numbers). Pie chart shows the percentage of total livestock in Gulbarga district. The minimum $5 \%$ livestock present in Afzalpur taluka of the district and maximum $19 \%$ of livestock percent in the Yadgir taluka of the district. To manage the livestock, at present there were 14 Goshalas in the district. It requires more additional number of Goshalas (Cattle sheds) to reduce the impact of drought on livestock. During drought, the animals should be kept in the cattle sheds and arrangements should be made to procure fodder from wherever it is available.

The Animal Husbandry and Veterinary Service Department should be placed in-charge of the cattle sheds for procurement of fodder and treatment of diseased animals. They should be cautioned to have sufficient stock of medicine in each of the Goshalas.

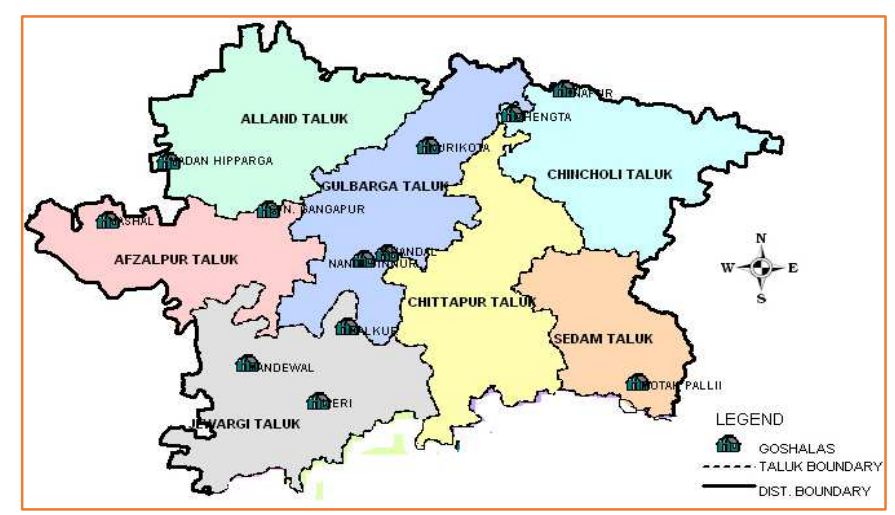

Fig.4 Location map showing no of Goshalas in Gulbarga district

\section{CONCLUSIONS}

1. Artificial recharging of aquifers to augment ground water by constructing percolation tanks and check dams across nallas and water courses.

2. Planning and development of works for drought mitigation such as water harvesting, social forestry, pasture development etc.

3. Development of appropriate and viable drought management strategies to meet the challenge posed by the occurrence of droughts year after year, should be the ultimate goal of drought research.

4. The wide variability in rainfall in drought prone mandals requires installation of rain gauge at Gram Panchayat level.

5. Artificial recharging of aquifers to augment ground water by constructing percolation tanks and check dams across nalas and water courses.

6. Planning and development of works for drought mitigation such as water harvesting, social forestry, pasture development etc.

7. Encouraging R \& D studies on drought resistant crops to suit semi-arid climate mixed cropping pattern, economic water use methods, techniques to minimize losses from water distribution systems and water bodies.

8. Weather modification through cloud seeding for inducing artificial rainfall for increasing the rainfall in the pockets of acute drought.

\section{REFERENCES}

[1] Mohan.S \& Mahesh.N (2004), Dependability of Irrigation and Hydropower during Drought,Journal of Indian water resources society, Vol. 24, no3, pp 1-11

[2] Ramdas L.A \& Mallik A. K (1948) Agricultural situation in India, Technical Bulletin, ICAR, New Delhi

[3] Banerji,S \& Bhhabra B.M (1963) Drought conditions in the Telangana division (AndhraPradesh) During the southwest monsoon season, Indian J. Metrology and Geophysics, 14(4), PP. 403-415.

[4] Sharma H.C. et al.(1987) Analysis of Rainfall Data for Agricultural Planning, Journal, Institution of engineers (India)- AG, 68: 1-6.

[5] Dabral P. P. (1996) Metrological drought analysis based on rainfall data. Indian J. soil Cons., 24(1), 37-40.

[6] Kumar.D \& Kumar.S (1989), Drought analysis based on rainfall data, Indian J. soil Cons., 17(1), pp. 55-60.

[7] Ray C.R et al. (1987), investigation of drought from rainfall data at Gopalau, Orrisa, Indian j. Soil cons., 15(1), pp. 15-19.

[8] Ranade .D.H. \& Gupta. R. (1992), Drought Analysis of Barwaha, Indian J. soilcons.,20(1\&2), pp. 83-85

[9] Tapeshwar Singh, (1978) Drought Prone Areas in India, People Publishing House, New Delhi, pp.26-29

[10] Sastry, P S N 2003 Agro Meteorological Aspects of Drought Management, Drought Management, Allied Publishers Private Limited New Delhi, pp.185-196 
[11] Report, 2006 on Statistics of the Gulbarga district, published by Z.P. Gulbarga, pp.1-25.

[12] Report of Government of Karnataka, 2003, Contingency plan for Drought Relief Work of Gulbarga district Administration, Z.P Gulbarga, pp. 1-10.

[13] Report, on Disaster Management Plans, 2006 Deputy Commissioner, Gulbarga District.pp.1-12 